\title{
Faktor-Faktor Yang Mempengaruhi Purchase Intention Generasi Milenial Pada Produk Pangan Organik
}

\author{
Trikadibusana, Anindya Angelina dan Laurentia Verina Halim Secapramana \\ Universitas Surabaya \\ angelina.anindya@yahoo.co.id
}

\begin{abstract}
Abstrak
Produk pangan organik merupakan produk yang semakin diminati oleh generasi milenial. Generasi milenial telah memasuki usia produktif dan akan menjadi tulang punggung perekonomian Indonesia. Penelitian ini mengungkap faktor-faktor yang mempengaruhi minat beli generasi milenial pada produk pangan organik. Theory of planned behavior dipilih sebagai kerangka teori utama pada penelitian ini bersama dengan beberapa variabel lain (environmental concern dan health consciousness) yang ditambahkan dalam model penelitian untuk memperluas penerapan theory of planned behavior. Data diperoleh dari dua ratus sebelas responden dan data dianalisis menggunakan Structural Equation Modeling (SEM). Hasil penelitian menunjukkan bahwa perceived behavioral control, attitude, dan health consciousness berpengaruh positif dengan hasil signifikan terhadap minat beli. Namun, subjective norm dan environmental concern ditemukan tidak memiliki pengaruh positif terhadap minat beli generasi milenial pada produk pangan organik.
\end{abstract}

Kata kunci: generasi milenial, minat beli, produk pangan organik, theory of planned behavior, extended theory of planned behavior

\begin{abstract}
Organic food products are gaining popularity in millennials. Millennials are entering the workforce and will be an important engine to the Indonesian economy. This study reveals the factors that influence millennials purchase intention toward organic food products. The theory of planned behavior is chosen as the main theoretical framework of this study alongside some other variables (environmental concern and health consciousness), which are added in the research model to expand theory of planned behavior application. Data were obtained from two hundred and eleven respondents and the data are analyzed using Structural Equation Modeling (SEM). The results showed that perceived behavioral control, attitude, and health consciousness had a positive effect with significant results on purchase intention. However, subjective norm and environmental concern did not influence the purchase intention toward organic food products among millennials.
\end{abstract}

Keywords: millennials, purchase intention, organic food products, theory of planned behavior, extended theory of planned behavior

\section{PENDAHULUAN}

\subsection{Latar Belakang}

Pemberdayaan sumber daya alam yang dilakukan manusia sering kali menjadi penyebab utama dari berbagai permasalahan lingkungan. Untuk menjaga kelestarian lingkungan, salah satu kunci yang dapat dilakukan adalah dengan menerapkan perilaku ramah lingkungan. Salah satu bentuk kontribusi yang dinilai signifikan terhadap peningkatan kualitas lingkungan adalah dengan mengonsumsi produk ramah lingkungan termasuk produk pangan organik [1].
Negara-negara berkembang merupakan pasar potensial untuk produk ramah lingkungan termasuk produk organik [2]. Generasi milenial Indonesia merupakan segmen yang potensial untuk produk organik. Generasi milenial menurut para ahli dari berbagai negara dan profesi, yaitu generasi yang lahir antara tahun 1980 sampai dengan 2000 [3]. Generasi milenial memiliki ciri-ciri tingkat pendidikan dan daya beli yang tinggi, ketertarikan terhadap tujuan sosial dan nilai-nilai komunitas, orientasi pada produk ramah lingkungan, serta perhatian tentang keamanan pangan dan kelestarian lingkungan 
[4]. Pada tahun 2020, generasi milenial memasuki usia produktif, yaitu berada pada rentang usia 20 hingga 40 tahun dan akan menjadi tulang punggung perekonomian Indonesia. Tahun 2020 juga merupakan saat dimulainya bonus demografi [3].

Teori yang dapat digunakan untuk menganalisis perilaku konsumen adalah Theory of Planned Behavior. Aplikasi kerangka Theory of Planned Behavior dapat diterapkan untuk mengetahui perilaku konsumen untuk memilih makanan, khususnya dalam konteks makanan organik $[5,6]$. Tidak terbatas pada ketiga faktor yang ada pada kerangka Theory of Planned Behavior saja, beberapa peneliti berpendapat bahwa ada variabel lain yang tidak termasuk dalam Theory of Planned Behavior yang penting untuk meningkatkan kemampuan model dalam memprediksi perilaku [7]. Mempertimbangkan hal tersebut, penelitian ini menggabungkan variabel yang terdapat pada model penelitian Wang et al. [8] dan Katt \& Meixner [9] untuk mengetahui minat beli konsumen di Indonesia, khususnya generasi milenial terhadap produk pangan organik dengan mengikutsertakan konsumen pangan organik baik yang reguler maupun sesekali untuk mendapatkan hasil yang lebih utuh. Penelitian ini menggunakan Theory of Planned Behavior dan menambahkan 2 variabel yang berperan untuk menjelaskan minat beli konsumen terhadap produk pangan organik berdasarkan dukungan teoritis dari berbagai literatur, yaitu environmental concern $[7,10,11]$ dan health consciousness $[2,10,12]$.

\subsection{Tujuan Penelitian}

Untuk mengetahui pengaruh subjective norm, perceived behavioral control, attitude, environmental concern, dan health consciousness terhadap purchase intention generasi milenial pada produk pangan organik.

\section{KAJIAN LITERATUR DAN PEMBENTUKAN HIPOTESIS}

\subsection{Subjective Norm}

Subjective norm adalah persepsi mengenai tekanan sosial yang diterima seseorang untuk melakukan atau tidak melakukan perilaku tertentu [13]. Secara umum, seseorang akan melakukan suatu perilaku ketika perbuatan tersebut dievaluasi secara positif dan ketika orang-orang terdekat atau yang dipercaya beranggapan bahwa perilaku tersebut perlu dilakukan [14]. Pada beberapa kasus, individu akan bergantung pada norma-norma yang ada dan diikuti untuk memutuskan apakah individu akan melakukan atau tidak akan melakukan suatu perilaku [15]. Hal ini menunjukkan hubungan antara subjective norm dan minat untuk melakukan tindakan pada setiap orang. Sebuah penelitian di Bangladesh telah berhasil membuktikan subjective norm memiliki pengaruh positif terhadap purchase intention produk pangan organik [16]. Demikian juga pada hasil penelitian di Malaysia [7], Tanzania dan Kenya [8] yang mampu membuktikan subjective norm memiliki pengaruh positif terhadap purchase intention produk pangan organik, sehingga pada penelitian ini muncul hipotesis:

$\mathrm{H}_{1}$ : Subjective norm berpengaruh positif terhadap purchase intention generasi milenial pada produk pangan organik

\subsection{Perceived Behavioral Control}

Perceived behavioral control merupakan persepsi individu mengenai kemudahan atau kesulitan untuk melakukan suatu perilaku [13]. Perceived behavioral control tergantung pada kemampuan dan hambatan yang dirasakan, sehingga dapat mempengaruhi purchase intention seseorang [8]. Hasil studi mengenai minat beli menunjukkan perceived behavioral control memiliki pengaruh yang besar pada minat beli konsumen di Asia [7]. Senada dengan hal itu, penelitian yang telah dilakukan mampu menunjukkan perceived behavioral control memiliki pengaruh positif terhadap purchase intention produk pangan organik di negara berkembang [8] dan konsumen generasi muda [2], sehingga pada penelitian ini muncul hipotesis:

$\mathrm{H}_{2}$ : Perceived behavioral control berpengaruh positif terhadap purchase intention generasi milenial pada produk pangan organik

\subsection{Attitude}

Attitude merupakan sejauh mana seseorang memiliki evaluasi atau penilaian mengenai baik atau tidaknya sebuah perilaku [13]. Seseorang yang yakin bahwa suatu perilaku dapat membawa dampak atau menghasilkan outcome yang positif, maka orang tersebut akan memiliki sikap yang positif terhadap perilaku 
tersebut [13]. Studi yang dilakukan pada konsumen muda di India [2] dan konsumen di Bangladesh [16] mampu membuktikan bahwa attitude berpengaruh positif terhadap purchase intention produk pangan organik. Studi lain juga menemukan hubungan positif antara attitude dengan purchase intention [15], sehingga pada penelitian ini muncul hipotesis:

$\mathrm{H}_{3}$ : Attitude berpengaruh positif terhadap purchase intention generasi milenial pada produk pangan organik

\subsection{Environmental Concern}

Environmental concern adalah sebuah kepedulian mengenai masalah lingkungan yang disebabkan oleh perilaku manusia [17]. Di seluruh dunia, orang-orang semakin menyadari perilaku konsumsi dan dampaknya terhadap lingkungan, kemudian menunjukkan kepedulian dengan berusaha mengurangi dampak tersebut [18]. Environmental concern memiliki peran penting dalam menentukan minat beli dari produk pangan organik [2]. Penelitian terdahulu mengungkapkan environmental concern merupakan motivator kuat untuk purchase intention produk pangan organik [7]. Beberapa penelitian yang telah dilakukan juga menunjukkan environmental concern berpengaruh positif terhadap purchase intention produk pangan organik $[5,7,9]$, sehingga pada penelitian ini muncul hipotesis:

$\mathrm{H}_{4}$ : Environmental concern berpengaruh positif terhadap purchase intention generasi milenial pada produk pangan organik

\subsection{Health Consciousness}

Health consciousness merupakan tingkat integrasi mengenai hal-hal yang berkaitan dengan kesehatan ke dalam aktivitas sehari-hari seseorang [8]. Health consciousness mengevaluasi kesiapan seseorang untuk melakukan tindakan yang menyehatkan [8]. Konsumen telah menyadari efek dari asupan makanan dan memahami risiko yang akan ditimbulkan oleh pestisida [7]. Oleh karena itu, konsumen cenderung beralih ke produk yang lebih sehat untuk melindungi diri dari dampak tersebut [11]. Health consciousness mampu digunakan untuk memprediksi minat beli konsumen dalam konteks pangan organik. Hasil penelitian menunjukkan konsumen muda menunjukkan minat pada masalah yang berkaitan dengan pangan dan kesehatan [2]. Hal ini didukung oleh beberapa hasil penelitian yang berhasil membuktikan health consciousness berpengaruh positif terhadap purchase intention produk pangan organik $[2,8,9]$, sehingga pada penelitian ini muncul hipotesis:

$\mathrm{H}_{5}$ : Health consciousness berpengaruh positif terhadap purchase intention generasi milenial pada produk pangan organik

\section{METODE}

Pendekatan yang dilakukan dalam penelitian ini adalah pendekatan kuantitatif. Berdasarkan tujuannya, penelitian ini termasuk dalam causal research karena penelitian ini mengidentifikasi hubungan sebab akibat antarvariabel [19]. Berdasarkan metode teoritis yang diusulkan, terdapat lima variabel yang berfungsi sebagai variabel eksogen dan satu variabel endogen. Subjective Norm (SN), perceived behavioral control ( $\mathrm{PBC})$, attitude (ATT), environmental concern (EC), dan health consciousness $(\mathrm{HC})$ adalah variabel eksogen sedangkan purchase intention (PI) adalah variabel endogen. Definisi operasional dari enam variabel tersebut didefinisikan berdasarkan penelitian Yadav \& Pathak [2], Wang et al. [8], Katt \& Meixner [9], dan Pacho [20].

Teknik pengambilan sampel yang digunakan dalam penelitian ini adalah nonprobability sampling. Jenis non-probability sampling yang digunakan adalah purposive sampling. Metode yang digunakan untuk mengumpulkan data adalah online survey menggunakan google form. Kuesioner disebarkan secara online pada periode November-Desember 2020. Sampel yang digunakan pada penelitian ini adalah pria atau wanita berusia 20-40 tahun dan pernah membeli dan mengonsumsi produk pangan organik dalam 6 bulan terakhir.

Dari 222 kuesioner yang terkumpul secara online, terdapat 211 responden yang memenuhi kriteria untuk diolah lebih lanjut. Jumlah responden telah memenuhi jumlah minimal sampel yang ditetapkan, yaitu 150 responden [21]. Data tersebut kemudian dianalisis menggunakan Structural Equation Model (SEM). SEM menggambarkan semua hubungan antarkonstruk yang terlibat dalam analisis dan dapat dianggap sebagai kombinasi 
unik dari berbagai jenis teknik karena fondasi SEM terletak pada 2 teknik multivariat, yaitu analisis faktor dan analisis regresi berganda [21]. 2 tahap pengolahan dan analisis data pada metode ini, yaitu measurement model dan structural model [21].

\section{HASIL DAN PEMBAHASAN}

Pada tahap awal analisis SEM, dilakukan analisis model pengukuran dengan metode Confirmatory Factor Analysis (CFA) untuk memastikan data penelitian valid dan reliabel.
Suatu indikator dikatakan valid apabila memiliki nilai standardized loading minimum 0,50 [21] dan nilai Average Variance Extracted (AVE) minimum 0,40 [22]. Selain itu, suatu indikator dikatakan reliabel apabila memiliki nilai Construct Reliability (CR) minimum 0,70 [21]. Hasil CFA telah memenuhi kriteria goodness of fit model (CMIN/DF = 1,783; RMSEA =0,061; GFI = 0,820; $\mathrm{CFI}=0,914$; dan $\mathrm{TLI}=0,905$ ) berdasarkan Hair et al. [21] dan menunjukkan model yang baik. Hasil CFA dapat dilihat pada Tabel 1.

Tabel 1. Hasil Confirmatory Factor Analysis

\begin{tabular}{|c|c|c|c|c|c|}
\hline Variabel & Indikator & Standardized Loading & AVE & $\mathrm{CR}$ & Keterangan \\
\hline \multirow{5}{*}{ Subjective Norm } & SN1 & 0.841 & & & \multirow{5}{*}{ Valid dan reliabe } \\
\hline & SN2 & 0.860 & & & \\
\hline & SN3 & 0.862 & 0.709 & 0.924 & \\
\hline & SN4 & 0.819 & & & \\
\hline & SN5 & 0.826 & & & \\
\hline \multirow{5}{*}{$\begin{array}{c}\text { Perceived } \\
\text { Behavioral } \\
\text { Control }\end{array}$} & PBC1 & 0.559 & & & \multirow{5}{*}{ Valid dan reliabe } \\
\hline & PBC2 & 0.601 & & & \\
\hline & РBC3 & 0.734 & 0.423 & 0.783 & \\
\hline & PBC4 & 0.725 & & & \\
\hline & PBC5 & 0.612 & & & \\
\hline \multirow{5}{*}{ Attitude } & ATT1 & 0.763 & & & \multirow{5}{*}{ Valid dan reliabe } \\
\hline & ATT2 & 0.698 & & & \\
\hline & ATT3 & 0.760 & 0.561 & 0.864 & \\
\hline & ATT4 & 0.754 & & & \\
\hline & ATT5 & 0.767 & & & \\
\hline \multirow{5}{*}{$\begin{array}{c}\text { Environmental } \\
\text { Concern }\end{array}$} & EC1 & 0.522 & & & \multirow{5}{*}{ Valid dan reliabe } \\
\hline & EC2 & 0.795 & & & \\
\hline & EC3 & 0.679 & 0.461 & 0.807 & \\
\hline & EC4 & 0.768 & & & \\
\hline & EC5 & 0.590 & & & \\
\hline \multirow{5}{*}{$\begin{array}{c}\text { Health } \\
\text { Consciousness }\end{array}$} & $\mathrm{HC1}$ & 0.648 & & & \multirow{5}{*}{ Valid dan reliabe } \\
\hline & $\mathrm{HC} 2$ & 0.522 & & & \\
\hline & $\mathrm{HC} 3$ & 0.719 & 0.435 & 0.792 & \\
\hline & $\mathrm{HC} 4$ & 0.661 & & & \\
\hline & HC5 & 0.727 & & & \\
\hline \multirow{5}{*}{$\begin{array}{l}\text { Purchase } \\
\text { Intention }\end{array}$} & PI1 & 0.814 & & & \multirow{5}{*}{ Valid dan reliabe } \\
\hline & $\mathrm{PI} 2$ & 0.813 & & & \\
\hline & $\mathrm{PI3}$ & 0.773 & 0.667 & 0.909 & \\
\hline & $\mathrm{PI} 4$ & 0.833 & & & \\
\hline & $\mathrm{PI5}$ & 0.849 & & & \\
\hline
\end{tabular}

Hasil CFA menunjukkan semua indikator memiliki nilai standardized loading $\geq 0,50$ dan semua variabel memiliki nilai AVE $\geq 0,40$ yang menunjukkan bahwa semua indikator dan variabel valid. Semua variabel juga dipastikan reliabel karena memiliki nilai construct reliability $\geq 0,70$. Setelah data penelitian terbukti valid dan reliabel, maka langkah selanjutnya adalah melakukan analisis model struktural dan menguji hipotesis. Hasil analisis model struktural telah memenuhi kriteria goodness of fit model (CMIN/DF = 1,783; RMSEA =0,061; GFI = 0,820; 
Jurnal Administrasi Dan Manajemen

$\mathrm{CFI}=0,914 ;$ dan $\mathrm{TLI}=0,905)$ berdasarkan Hair et al. [21] dan

Tabel 2. Profil Demografi Responden

\begin{tabular}{|c|c|c|c|}
\hline & Keterangan & Jumlah & Persentase \\
\hline \multirow{2}{*}{ Jenis Kelamin } & Laki-laki & 97 & $45.97 \%$ \\
\hline & Perempuan & 114 & $54.03 \%$ \\
\hline \multirow{4}{*}{ Usia } & 20-25 tahun & 165 & $78.20 \%$ \\
\hline & 26-30 tahun & 18 & $8.53 \%$ \\
\hline & 31-35 tahun & 6 & $2.84 \%$ \\
\hline & 36-40 tahun & 22 & $10.43 \%$ \\
\hline \multirow{8}{*}{ Kota Domisili } & Jakarta & 33 & $15.64 \%$ \\
\hline & Surabaya & 66 & $31.28 \%$ \\
\hline & Samarinda & 34 & $16.11 \%$ \\
\hline & Tangerang & 14 & $6.64 \%$ \\
\hline & Bandung & 7 & $3.32 \%$ \\
\hline & Bali & 7 & $3.32 \%$ \\
\hline & Bekasi & 6 & $2.84 \%$ \\
\hline & Lainnya & 44 & $20.85 \%$ \\
\hline \multirow{5}{*}{ Pendidikan Terakhir } & SMA/ SMK & 69 & $32.70 \%$ \\
\hline & Diploma & 9 & $4.27 \%$ \\
\hline & S1 & 128 & $60.66 \%$ \\
\hline & S2 & 5 & $2.37 \%$ \\
\hline & S3 & - & - \\
\hline \multirow{5}{*}{ Pekerjaan } & Pelajar/ Mahasiswa & 95 & $45.02 \%$ \\
\hline & Pegawai Negeri & 1 & $0.49 \%$ \\
\hline & Pegawai Swasta & 62 & $29.38 \%$ \\
\hline & Wirausahawan & 47 & $22.27 \%$ \\
\hline & Lainnya & 6 & $2.84 \%$ \\
\hline \multirow{5}{*}{ Pendapatan } & $<\operatorname{Rp} 3.000 .000$ & 81 & $38.39 \%$ \\
\hline & Rp 3.000.000 - Rp 7.999.999 & 85 & $40.28 \%$ \\
\hline & Rp 8.000.000 - Rp 12.999.999 & 28 & $13.27 \%$ \\
\hline & Rp 13.000.000 - Rp 17.999.999 & 4 & $1.90 \%$ \\
\hline & $>\operatorname{Rp} 18.000 .000$ & 13 & $6.16 \%$ \\
\hline \multicolumn{2}{|c|}{ Total Responden } & & \\
\hline
\end{tabular}

Sumber: Profil Responden Generasi Milenial

Tabel 3. Profil Responden Terkait Produk Pangan Organik

\begin{tabular}{clcc}
\hline & \multicolumn{1}{c}{ Keterangan } & Jumlah & Persentase \\
\hline \multirow{3}{*}{ Produk Pangan Organik yang Paling } & Beras & 65 & $30.81 \%$ \\
Sering dibeli & Telur & 47 & $22.28 \%$ \\
& Sayuran & 56 & $26.54 \%$ \\
& Buah-buahan & 38 & $18.00 \%$ \\
& Lainnya & 5 & $2.37 \%$ \\
\hline \multirow{2}{*}{ Frekuensi Membeli Produk Pangan } & 1 kali & 29 & $13.74 \%$ \\
Organik dalam 1 Bulan & 2 kali & 62 & $29.38 \%$ \\
& 3 kali & 43 & $20.38 \%$ \\
& 4 kali & 42 & $19.91 \%$ \\
\multirow{2}{*}{ Lama Mengonsumsi Produk Pangan } & $>4$ kali & 35 & $16.59 \%$ \\
\hline Organik & $1-6$ bulan & 42 & $19.91 \%$ \\
& $7-12$ bulan & 40 & $18.95 \%$ \\
& $>1$ tahun & 129 & $61.14 \%$ \\
\hline
\end{tabular}

Sumber: Profil Responden Generasi Milenial 
menunjukkan bahwa model struktural dalam penelitian ini baik dan dapat diinterpretasikan lebih lanjut. Profil demografi responden dapat dilihat pada Tabel 2 dan profil responden terkait produk pangan organik pada Tabel 3.

Hasil uji hipotesis penelitian ini tersaji pada Tabel 4. Hasil uji hipotesis menunjukkan bahwa tidak semua variabel dapat memiliki pengaruh terhadap purchase intention generasi milenial pada produk pangan organik. Hal ini dapat dilihat dari 5 hipotesis yang ada, 3 hipotesis dinyatakan terdukung dan 2 hipotesis dinyatakan tidak terdukung. Attitude dan perceived behavioral control memiliki hasil yang positif dan signifikan dalam mempengaruhi purchase intention sedangkan subjective norm tidak menunjukkan pengaruh yang signifikan terhadap purchase intention. Oleh karena itu, H2 dan $\mathrm{H} 3$ terdukung sedangkan $\mathrm{H} 1$ tidak terdukung. $\mathrm{Di}$ antara variabel yang terdapat pada kerangka Theory of Planned Behavior, attitude memberikan pengaruh terbesar dalam menjelaskan pengaruh purchase intention terhadap produk pangan organik diikuti oleh perceived behavioral control. Health consciousness juga ditemukan memiliki pengaruh yang positif dan signifikan dalam mempengaruhi purchase intention, namun berbeda dengan environmental concern yang tidak terbukti memiliki pengaruh positif dan signifikan terhadap purchase intention. Oleh karena itu, H5 terdukung dan $\mathrm{H} 4$ tidak terdukung.

Hasil penelitian menunjukkan bahwa attitude dan perceived behavioral control secara signifikan mempengaruhi purchase intention generasi milenial pada produk pangan organik sedangkan subjective norm tidak menunjukkan pengaruh yang signifikan terhadap purchase intention. Hal ini menunjukkan semakin besar perasaan senang atau yakin dengan manfaat yang akan diperoleh, maka semakin tinggi pula minat generasi milenial untuk membeli produk pangan organik.

Produk pangan organik dianggap sebagai pilihan yang baik karena memiliki keunggulan nutrisi bila dibandingkan dengan produk pangan konvensional (non-organik) [11]. Pada penelitian ini, attitude ditemukan memberikan pengaruh terbesar dalam menjelaskan pengaruh purchase intention terhadap produk pangan organik, konsisten dengan penelitian terdahulu [7, 23]. Lebih lanjut, minat beli generasi milenial pada produk pangan organik juga ditentukan oleh perceived behavioral control. Hal ini menunjukkan keterbatasan dan kemampuan yang dirasakan terkait harga dan ketersediaan produk dapat mempengaruhi minat beli konsumen [8]. Sementara itu, subjective norm ditemukan tidak memiliki pengaruh signifikan terhadap minat beli generasi milenial pada produk pangan organik. Hal ini menandakan persetujuan dari orangorang terdekat bukan merupakan faktor yang penting untuk membeli produk tersebut [24]. Selain itu, membeli makanan organik belum menjadi norma di negara berkembang [2].

Variabel di luar kerangka Theory of Planned Behavior yang berperan untuk menjelaskan minat beli konsumen terhadap produk pangan organik, yaitu health consciousness juga terbukti mempengaruhi purchase intention generasi milenial pada produk pangan organik. Hasil ini konsisten dengan temuan Wang et al. [8], Katt \& Meixner [9], dan Chu [12]. Hal ini menunjukkan generasi milenial memiliki kesadaran kesehatan yang tinggi dan menganggap kesehatan sebagai parameter penting saat ingin membeli produk pangan. Chu [12] menuturkan konsumen pada masa kini membeli produk pangan organik

Tabel 4. Hasil Uji Hipotesis

\begin{tabular}{|c|c|c|c|c|c|}
\hline Hipotesis & $\begin{array}{c}\text { Hubungan } \\
\text { antarvariabel }\end{array}$ & $\begin{array}{c}\text { Nilai } \\
\text { Standardized } \\
\text { Estimate }\end{array}$ & C.R & P-Value & Keterangan \\
\hline $\mathrm{H} 1$ & $\mathrm{SN} \rightarrow \mathrm{PI}$ & .133 & 1.894 & .058 & Hipotesis tidak terdukung \\
\hline $\mathrm{H} 2$ & $\mathrm{PBC} \rightarrow \mathrm{PI}$ & .210 & 2.230 & .026 & Hipotesis terdukung \\
\hline $\mathrm{H} 3$ & $\mathrm{ATT} \rightarrow \mathrm{PI}$ & .429 & 3.487 & $* * *$ & Hipotesis terdukung \\
\hline $\mathrm{H} 4$ & $\mathrm{EC} \rightarrow \mathrm{PI}$ & -.067 & -.834 & .404 & Hipotesis tidak terdukung \\
\hline $\mathrm{H} 5$ & $\mathrm{HC} \rightarrow \mathrm{PI}$ & .296 & 3.336 & $* * *$ & Hipotesis terdukung \\
\hline
\end{tabular}

Keterangan: $* * *$ signifikan pada $p$-value $\leq 0,01$ 


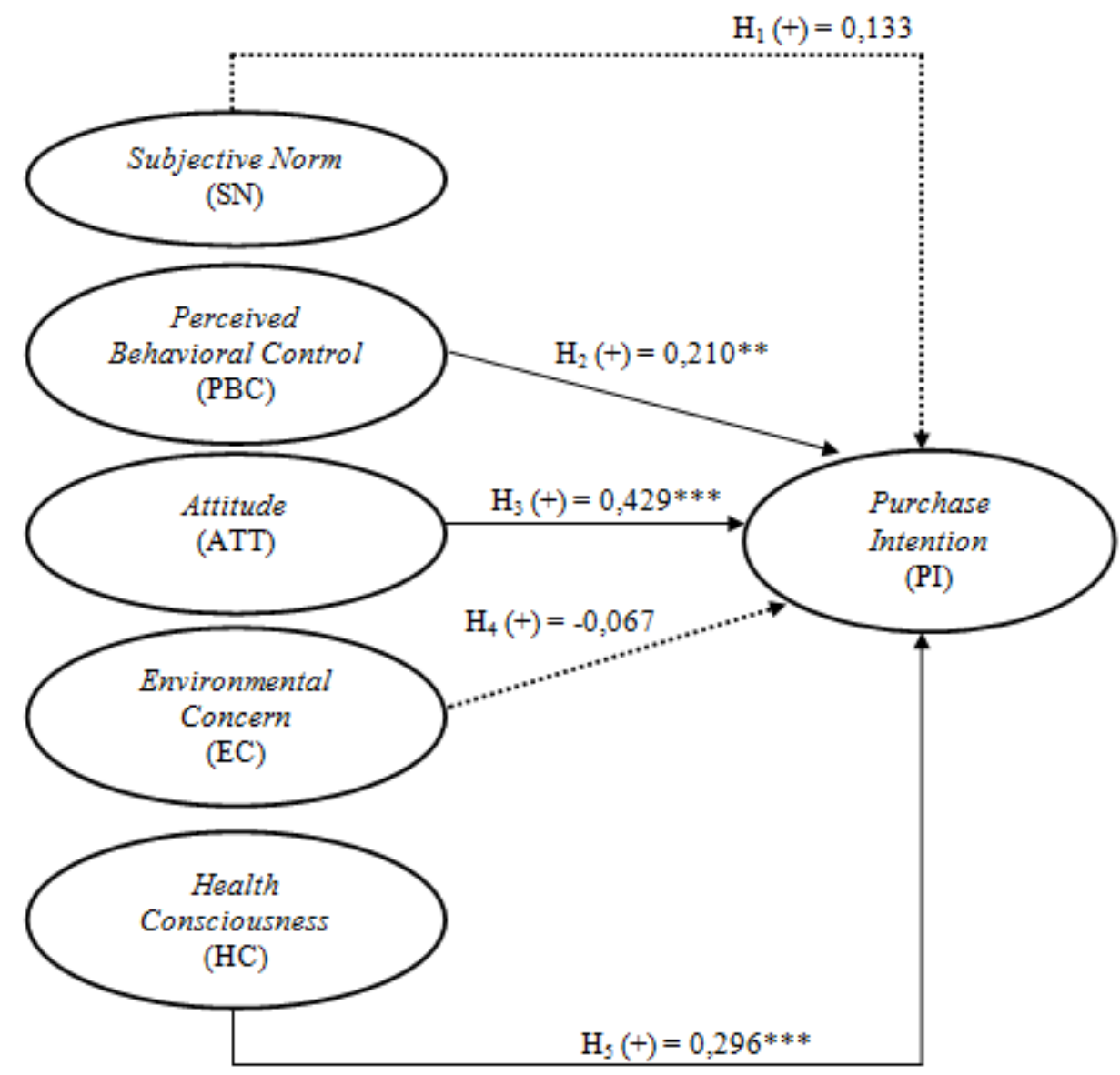

Keterangan:

$* * *$ Koefisien signifikan pada $p$-value $\leq 0,01$

$* *$ Koefisien signifikan pada $p$-value $\leq 0,05$

\section{Gambar 1. Hasil Analisis Model Struktural}

sebagai sebuah bentuk investasi yang mencerminkan tingkat kesadaran dan perhatian individu terhadap kesehatan semakin tinggi. Namun, environmental concern ditemukan tidak memiliki pengaruh positif dan signifikan terhadap minat beli produk pangan organik. Hal ini menunjukkan faktor yang mempengaruhi konsumen muda untuk membeli pangan organik bukanlah perilaku altruistik seperti kepedulian terhadap lingkungan, melainkan pertimbangan egoistik seperti kesehatan $[11,25]$. Ilustrasi hasil analisis model struktural dapat dilihat pada Gbr. 1.

\section{KESIMPULAN DAN SARAN}

Penelitian ini bertujuan untuk mengungkap faktor-faktor yang mempengaruhi minat beli generasi milenial pada produk pangan organik di Indonesia. Dengan menggunakan variabel yang terdapat pada kerangka Theory of Planned Behavior, hasil penelitian ini memberikan pemahaman yang lebih mendalam mengenai faktor-faktor yang mempengaruhi minat beli terhadap produk pangan organik di kalangan generasi milenial.

Analisis terhadap dua ratus sebelas data empiris membuktikan bahwa dua dari lima hipotesis tidak terdukung. Hasil penelitian menunjukkan minat beli generasi milenial pada produk pangan organik secara positif dipengaruhi oleh attitude, perceived behavioral control, dan health consciousness sedangkan subjective norm dan environmental concern tidak mempengaruhi minat beli terhadap produk pangan organik. Temuan ini memberikan kontribusi teoritis dalam menjelaskan minat beli produk pangan organik terutama di kalangan generasi milenial di negara berkembang. Penambahan variabel environmental concern dan health consciousness pada kerangka Theory of Planned Behavior memberikan kontribusi 
penjelasan yang lebih baik dalam memahami minat beli produk pangan organik.

Secara praktis, hasil ini memberikan wawasan manajerial untuk mengedukasi konsumen mengenai proses pengolahan dan keunggulan produk pangan organik, sehingga membuat masyarakat lebih teredukasi dan percaya pada manfaat yang akan diterima bila mengonsumsi produk pangan organik. Kesadaran konsumen tentang kesehatan juga perlu ditingkatkan dengan menyampaikan pentingnya memilih produk pangan yang baik dan perbedaan proses pengolahan produk pangan organik dan konvensional, kandungan nilai gizi, serta dampak yang ditimbulkan bagi tubuh. Selain itu, perusahaan sebaiknya menyalurkan produk pangan organik ke lebih banyak tempat perbelanjaan yang mudah dijangkau oleh konsumen, baik offline seperti supermarket dan minimarket maupun online seperti marketplace. M-commerce dan pemasaran berbasis aplikasi cenderung lebih penting karena saat ini konsumen Indonesia semakin terhubung melalui internet dan smartphone.

Penelitian terhadap suatu produk atau merek produk pangan organik dapat menjadi pertimbangan objek bagi penelitian selanjutnya untuk mendapat hasil yang lebih fokus dan spesifik. Selain itu, perlu juga dilakukan penelitian di lain waktu terkait topik produk pangan organik untuk mendapatkan hasil yang lebih baik karena data penelitian ini diambil saat terjadi pandemi covid-19 dan tidak menutup kemungkinan dapat mempengaruhi persepsi responden saat survei dilakukan seperti kondisi ekonomi dan ketersediaan produk.

\section{DAFTAR PUSTAKA}

1. Pham, T. H., Nguyen, T. N., Phan, T. T. H., \& Nguyen, N. T. Journal of Strategic Marketing 27, (2018) 540-556.

2. Yadav, R., \& Pathak, G. S. Appetite 96, (2016) $122-128$

3. Budiati, I., Susianto, Y., Adi, W. P., Ayuni, S., Reagan, H. A., Larasaty, P., Setiyawati, N., Pratiwi, A. I., \& Saputri, V. G. Statistik gender tematik: Profil generasi milenial Indonesia, Kementerian Pemberdayaan Perempuan dan Perlindungan Anak, Jakarta, 2018.
4. Molinillo, S., Branco, M. V., \& Japutra, A. Journal of Retailing and Consumer Services 52, (2019) 1-9.

5. Maichum, K., Parichatnon, S., \& Peng K. C. Sustainability $8,(2016)$ 1-20.

6. Liu, M. T., Liu, Y., \& Mo, Z. Asia Pacific Journal of Marketing and Logistics 32, (2020) 1823-1841.

7. Saleki, R., Quoquab, F., \& Mohammad, J. Journal of Agribusiness in Developing and Emerging Economies 9, (2019) 584603.

8. Wang, X., Pacho, F., Liu, J., \& Kajungiro, R. Sustainability 11, (2019) 1-18.

9. Katt, F., \& Meixner, O. Foods 9, (2020) 1-13.

10. Baudry, J., Péneau, S., Allès, B., Touvier, M., Hercberg, S., Galan, P., Amiot, M. J., Lairon, D., Méjean, C., \& Guyot, E. K. Nutrients 9, (2017) 88-104.

11. Dangi, N., Gupta, S. K., \& Narula, S. A. Management of Environmental Quality 31, (2020) 1515-1530.

12. Chu, K. M. Sustainability 10, (2018), 1-15.

13. Ajzen, I. Organizational Behavior and Human Decision Processes 50, (1991) 179-211.

14. Ajzen, I [Ed.]. From intentions to actions: A theory of planned behavior, SpringerVerlag, Berlin, 1985.

15. Ngoc, T. P. B., \& Buavaraporn, N. UTCC International Journal of Business and Economics 11, (2019) 113-127.

16. Rahman, K. M., \& Noor, N. A. M. International Business Management 10, (2016) 4292-4300.

17. Schultz, P. W., Gouveia, V. V., Cameron, L. D., Tankha, G., Schmuck, P., \& Franek, M. Journal of Cross-Cultural Psychology 36, (2005) 457-475.

18. Moser, A. K. Journal of Retailing and Consumer Services 31, (2016) 389-397.

19. Zikmund, W. G., Babin, B. J., Carr, J. C., \& Griffin, M. Business Research Methods $8^{\text {th }}$ ed, South-Western College Pub, New York, 2009.

20. Pacho, 2020. British Food Journal 122, (2020) 3695-3709.

21. Hair, J. F., Black, W. C., Babin, B. J., \& Anderson, R. E. Multivariate Data Analysis $7^{\text {th }}$ ed, Pearson Education Limited, London, 2014. 
Jurnal Administrasi Dan Manajemen

22. Huang, C. C., Wang, Y. M., Wu, T. W., \& Wang, P. A. International Journal of Information and Education Technology 3, (2013) 217-221.

23. Ajzen, I. Rivista Di Economia Agraria 70, (2015) 121-138.
24. Paul, J., Modi, A., \& Patel, J. Journal of Retailing and Consumer Services 29, (2016) 123-134.

25. Melović, B., Dabić, M., Rogić, S., Đurišić, V. and Prorok, V. British Food Journal 122, (2020) 1130-1155. 